p-ISSN: $2338-4794$

e-ISSN: 2579-7476

Vol.7. No. 3 September-Desember 2019

\title{
IMPLEMENTASI DIGITAL MARKETING TERHADAP KEPUTUSAN PEMBELIAN KONSUMEN JD.id Jakarta
}

\author{
Glen Irwinto Laluyan 1) \\ 1) Mahasiswa Program Studi Manajemen FE UNKRIS \\ Email : glenirwintolaluyan@gmail.com \\ Imam Wibowo ${ }^{2)}$ \\ 2) Dosen Program Studi Manajemen FE UNKRIS \\ Email : wibowoimam253@gmail.com \\ Amanda Setiorini ${ }^{3)}$ \\ 3) Dosen Program Studi Manajemen FE UNKRIS \\ Alamat: Kampus UNKRIS, Jatiwaringin Jakarta Timur \\ Email : amanda.setiorini@unkris.ac.id
}

\begin{abstract}
This research is about Implementation of Digital Marketing on Consumers Purchasing Decisions. This research aims to analize the implementation of the Social Media Marketing, Pay Per Click and Email Marketing to the Purchasing Decisions of Jakarta JD.id Consumers. In this research the sample took 100 respondent using purposive sampling technique, which respondent is an active user of the face book forum and has shopped on the JD.id site. The data that has been obtained tested using multiple linear regression analysis technique. The result that shown from this research are Social Media Marketing, Pay Per Click and Email Marketing simultaneous and partial gave positive and significant effect to Consumers Purchasing Decisions.
\end{abstract}

Keyword: Social media marketing, pay per click, email marketing, consumers purchasing decisions

\section{PENDAHULUAN}

Setiap perusahaan akan berusaha untuk dapat terus bertahan dan bersaing di dalam industrinya. Memahami dan dapat mempengaruhi keputusan pembelian konsumen dapat mendukung perusahaan bertahan di dalam persaingan.Perusahaan dituntut untuk selalu berinovasi dan berkreatifitas untuk dapat memperoleh konsumen baru maupun mempertahankan konsumen lama. Upaya untuk mempengaruhi keputusan pembelian tersebut tidak hanya dengan menjanjikan product functional dan good services, akan tetapi pemasar harus dapat mengetahui apa yang sedang dibutuhkan atau yang sedang diinginkan oleh konsumen pada saat ini. Melakukan komunikasi dua arah secara efektif terhadap konsumen dinilai akan menjadi faktor penentu keputusan pembelian pada konsumen.

Menurut Kotler dan Amstrong (2016), "keputusan pembelian adalah bagian dari perilaku konsumen, 
sementara perilaku konsumen adalah studi yang menyelidiki bagaimana perorangan, kelompok, dan organisasi yang memilih, membeli, menggunakan dan bagaimana barang, jasa, ide dan pengalaman selalu memuaskan dan mengendalikan kebutuhan dan keinginan diri". Banyak faktor yang mempengaruhi keputusan pembelian, misalnya adalah digital marketing. Adapun itu, dalam era pemasaran saat ini digital marketing merupakan sarana yang kini tidak terbatas dalam bentuk apapun, dimana pemasar bebas melakukan kreatifitas tanpa batas dalam berpromosi yang sebelumnya menggunakan media promosi konvensional.

Menurut Sanjaya dan Tarigan (2009), "digital marketing merupakan kegiatan promosi brand yang menggunakan berbagai media berbasis web seperti blogs, website, email, adwords, ataupun social media". Dan menurut Stokes (2013), "Pemasaran digital dapat didefinisikan sebagai pengunaan saluran digital untuk memasarkan merek. Kemudian untuk membangun definisi ini pemasaran digital didukung oleh internet, yang merupakan media interaktif yang memungkinkan terjadinya pertukaran informasi". Selanjutnya Stokes (2011), menyatakan bahwa "untuk menjangkau kosumen dengan digital marketing digunakan beberapa saluran yaitu social media marketing, pa yper click, dan email marketing"

Pengaruh ketiga saluran digital marketing tersebut diperkuat pada pertumbuhan teknologi yang semakin pesat dengan seiring adanya Smartphone dengan harga yang sangat terjangkau dipasar maka tidak heran jika tingkat perkembangan dan tingkat penetrasi penggunaan internet khususnya Indonesia melaju relatif cukup tinggi. Terlebih lagi sejumlah aplikasi melakukan terobosan yang menarik untuk memperluas interaksi dengan penggunanya, antara pengguna dengan pengguna yang lainnya (Kementrian Komunikasi dan Informatika, 2015). Diketahui bahwa populasi penduduk Indonesia mencapai 265.4 juta orang dan 50 persen atau sekitar 132.7 juta orang telah terhubung pada jaringan internet sepanjang tahun 2018. Mayoritas pengguna jasa internet masih dari kalangan masyarakat urban, pengunaan dan pemanfaatannya sudah lebih jauh bukan hanya berkomunikasi akan tetapi juga membeli suatu barang, melakukan pemesanan transportasi, hingga bisnis dan berkarya (https://aseanup.com/top-ecommerce-sites-indonesia, 2018).

$$
\text { Menurut Meson (2018), }
$$
"pengaruh perkembangan teknologi digital marketing di Indonesia menyebabkan bermunculan $e$ commerce atau marketplace online yang menyediakan kemudahan berbelanja barang ataupun jasa dengan pelayanan yang efektif dan optimal, maka dari itu keputusan pembelian merupakan hasil dari apa yang dibuat terhadap variabel digital marketing". Menurut Pratiwi (2018), "Kesibukan masyarakat saat ini dengan berbelanja secara konvensional memungkinkan ketidak efisien dan efektifnya dalam berbelanja, dikarenakan waktu serta biaya-biaya lain yang dikeluarkan jika pembeli harus membeli secara konvensional". Penelitian terhadap $e$ commerce JD.id.com, yang merupakan trobosan digital marketing baru didunia modern dengan memasarkan serta melakukan transaksi jual beli melalui Internet dengan sistem online 
marketing menjadi menarik seperti apa dampak adanya digital marketing terhadap keputusan pembelian. Posisi JD.id menempati posisi ke-6 dari $e$ commerce lainnya di Indonesia, sudah 3 tahun berjalan dari tanggal berdirinya November 2015 sampai saat ini received funding ditahun 2018 mencapai 16,9 Million USD. Menunjukan perkembangan yang sangat pesat terhadap kepercayaan dari pada konsumen untuk terus meluangkan waktunya bertransaksi di dalam marketplace tersebut (Source: https://aseanup.com/top-e-commercesites-indonesia, 2018).

$$
\text { Reddy (2016), "pada }
$$

penelitiannya yang berjudul "digital marketing impact on the consumer decision making", menemukan bahwa dampak digital marketing membawa pengaruh terhadap consumer perception dan purchase decision". Selain itu, Sivasankaran (2017) dalam penelitiannya yang berjudul "digital marketing and its impact on buying decision of youth", "menyatakan bahwa pemasaran digital mempunyai banyak ancaman dan tantangan dipasar online yang kompetitif dan pemasaran digital pun mempengaruhi keputusan konsumen muda"

\section{LANDASAN TEORI}

\section{Keputusan Pembelian}

Menurut Tjiptono (2008), keputusan pembelian adalah"sebuah proses dimana konsumen mengenal masalahnya, mencari informasi mengenai produk atau merek tertentu dan mengevaluasi seberapa baik masing-masing alternatif tersebut dapat memecahkan masalahnya, yang kemudian mengarah kepada keputusan pembelian". Berbeda dengan
Schiffman dan Kanuk (2009) yang mendeskripsikan keputusan pembelian"sebagai keputusan seseorang dimana dia memilih salah satu dari beberapa alternatif pilhan yang ada". Artinya bahwa seseorang bisa membuat keputusan, harus tersedia beberapa alternatif pilihan. Keputusan untuk membeli bisa mengarah pada bagaimana proses dalam pengambilan keputusan tersebut itu dilakukan. Berdasarkan definisi diatas dimaknai bahwa keputusan pembelian adalah tindakan yang dilakukan konsumen untuk melakukan pembelian sebuah produk. Oleh karena itu, pengambilan keputusan pembelian konsumen merupakan suatu proses pemilihan salah satu dari beberapa alternatif penyelesaian masalah dengan tindak lanjut yang nyata. Setelah itu konsumen dapat melakukan evaluasi pilihan dan kemudian dapat menentukan sikap yang akan diambil selanjutnya.

Menurut Kotler \& Amstrong (2016), terdapat lima proses pengambilan keputusan yaitu pengenalan akan kebutuhan, evaluasi alternatif, keputusan pembelian, perilaku pasca pembelian". keputusan mempunyai struktur yang terdiri dari tujuh komponen. Menurut Dharmmesta dan Handoko (2012), "komponen-komponen tersebut yaitu sebagai berikut : keputusan jenis produk, keputusan bentuk produk, keputusan merek, keputusan tentang penjualnya, keputusan jumlah produk, keputusan waktu pembelian, dan keputusan cara pembayaran".

\section{Social Media Marketing}

Menurut Gunelius

(2011), "social media marketing merupakan sistem dari pemasaran langsung 
ataupun tidak langsung yang menimbulkan kesadaran, pengenalan, pengigatan kembali, dan pengambilan aksi terhadap sebuah brand, bisnis, produk, orang, atau hal lainnya yang dikemas menggunakan alat-alat dari jejaring sosial". Social media marketing menggunakan sosial media sebagai saluran pemasarannya, sehingga dapat memanfaatkan ciri karakteristik dari sosial media sebagai dimensi pengukurannya.

Menurut Gunelius (2011), terdapat 4 sub yang dijadikan sebagai variabel keberhasilan social media marketing: 1). Content creation yaitu konten yang disajikan secara menarik menjadikan landasan strategi dalam melakukan pemasaran media social. Isi yang dibuat harus semenarik mungkin serta harus mewakili perilaku dan kepribadian dari sebuah bisnis agar dapat menggaet kepercayaan oleh target konsumen. 2). Content sharing kepada social community dapat membantu menambah jaringan sebuah bisnis dan menambah online audience. Content sharing dapat mempengaruhi penjualan tergantung seberapa kuat ketertarikan konten tersebut terhadap konsumen. 3). Connecting yaitu social networking memungkinkan semua orang bertemu dengan lebih banyak orang yang mempunyai selera dan minat yang sama. Jaringan yang luas dapat membuat hubungan yang menghasilkan lebih banyak bisnis. 4). Community building, social web adalah sebuah big community individual online dimana terjadi komunikasi antar manusia yang tinggal di seluruh dunia dengan memanfaatkan teknologi. Membangun komunitas di internet yang mempunyai kesamaan minat dapat terjadi pada jejaring sosial.

\section{Pay Per Clik (PPC)}

Dalam jenis sistem periklanan mesin pencari dikenal sebagai pay per click (PPC), pengguna membayar pencarian mesin dengan biaya tertentu. Logikanya adalah membayar uang per klik. Halaman web hanya melakukan pembayaran ketika iklan mereka diklik dan pengguna diarahkan ke halaman mereka. search engine optimization (SEM) menggunakan PPC sebagai contoh advertiser memasang system pemasaran menggunakan PPC dengan ilustrasi setiap 1 klik harus membayar kepada penyedia layanan PPC Rp.500/klik, advertiser menginginkan 1000 klik, jadi advertiser harus menyediakan Rp. 500,000 untuk membayar kepada penyedia layanan atas pengguna jasa PPC tersebut, ilustrasi tersebut merupakan komisi yang diperoleh penyedia layanan atas mempromosikan penjualan pada internet. Menurut Stokes (2011), "Periklanan PPC digunakan untuk sejumlah saluran dan platform. Cukup hanya, pengiklan membayar ketika pengguna mengklik iklan. Periklanan PPC biasanya dijalankan sebagai model lelang, sehingga pengiklan menempatkan tawaran untuk muncul berdasarkan kriteria tertentu. Platform iklan menentukan kapan iklan memenuhi syarat untuk muncul dan melayani mereka sebagaimana mestinya. Pengiklan kemudian membayar platform iklan pada saat kapan iklan mereka diklik".

\section{Email Marketing}

Fariborzi dan Zahedifard (2012), "email marketing merupakan bentuk pemasaran langsung yang digunakan sebagai sarana komunikasi komersial atau pesan penggalangan dana untuk audiens. Dalam arti luas, setiap email 
yang dikirim ke pelanggan potensial atau saat ini bisa dianggap email marketing". Namun, istilah itu biasanya digunakan untuk merujuk ke: 1). mengirim pesan email dengan tujuan meningkatkan hubungan pedagang dengan pelanggan sebelumnya, untuk mendorong loyalitas peanggan dan mengulang bisnis. 2). mengirim pesan email dengan tujuan memperoleh pelanggan baru atau meyakinkan pelanggan saat ini untuk segera membeli sesuatu. 3). menambah iklan ke pesan email yang dikirim oleh perusahaan kepada pelanggan mereka atau orang lain.

$$
\text { Menurut Chaffey (2011), }
$$
terdapat 3 faktor pada email marketing yang bisa dijadikan sebagai indikator, yaitu: 1). Email promosi yaitu berisikan tentang promosi sesuatu, seperti promosi new product, special offering, discount dan lain lain. 2). Email inspirasional. Email marketing seperti ini pada umumnya berisi tentang kisah sukses atau studi kasus, tentang kemampuan pada produk atau service dari perusahaan dan produk tertentu, saat menghadapi masalah tertentu lengkap dengan pilihan solusi. 3). Email informasi. Email tersebut merupakan email yang umumnya menyangkut informasi perkembangan perusahaan yang tidak secara langsung ada hubungannya dengan produk, dimaksudkan sebagai information email.

\section{Hipotesis}

$\mathrm{H}_{1}$ : Terdapat pengaruh implementasi social media marketing terhadap keputusan pembelian.

$\mathrm{H}_{2}$ : Terdapat pengaruh implementasi pay per click terhadap keputusan pembelian.
$\mathrm{H}_{3}$ : Terdapat
pengaruh implementasi email marketing terhadap keputusan pembelian.
$\mathrm{H}_{4}$ : Terdapat pengaruh implementasi social media marketing, pay per click dan email marketing terhadap keputusan pembelian.

\section{METODE PENELITIAN}

\section{Rancangan Penelitian}

Penelitian ini dirancang untuk menganalisis implementasi digital marketing terhadap keputusan pembelian. Diharapkan dari hasil penelitian diperoleh gambaran bagaimana pengaruh dari implementasi digital marketing terhadap keputusan pembelian, khususnya konsumen yang berbelanja melalui JD.id. Data yang digunakan dalam penelitian ini merupakan data primer melalui pengisian kuesioner oleh konsumen yang berbelanja melalui internet dengan sistem online marketing pada e-commerce JD.id.com dan disebarkan melalui online forum facebook.com JD.id.

\section{Metode Pengumpulan Data}

Penelitian ini dilakukan pada perusahaan JD.id.com, khususnya untuk mengatahui keputusan pembelian konsumen yang berbelanja berbagai produk yang dijual di JD.id. Jakarta. Data yang yang dikumpulkan adalah data primer melalui pengisian kuesioner yang disebarkan melalui online forum facebook.com JD.id.

Populasi dalam penelitian ini adalah pengguna aktif dari offocial JD.id pada aplikasi media sosial jejaring facebook Indonesia yang berjumlah 783.800 pengguna. (diakses dari https://www.facebook.com/JDid). 
Adapun sampel yang diambil pada penelitian ini nantinya dipilih berdasarkan suatu kriteria dan pertimbangan tertentu (purposive sampling), yaitu dengan cara mencari pengguna aktif dari forum facebook yang mengetahui, pernah mengunjungi dan ataupun pernah berbelanja di situs JD.id.com. daftar pengguna dengan kriteria tersebut dapat didentifikasikan melalu partisipasi pengguna pada kolom komentar official dan community group JD.id.com yang mendiskusikan seputar marketplace JD.id pada topik promotion, product dan services. Para pengguna tersebut kemudian diberikan pesan permohonan pengisian kuisioner secara online melalui private message di situs facebook. Responden yang berpartisipasi kemudian disaring kembali berdasarkan kriteria yaitu, berdomisili DKI Jakarta dan pernah melakukan pembelian disitus marketplace JD.id.com dalam 6 bulan terakhir terhitung sejak April - Juli Hasil Uji Hipotesis
2019. Adapun jumlah sampel yang diperoleh dengan menggunakan rumus slovin diperoleh sebanyak 100 responden.

\section{HASIL DAN PEMBAHASAN}

\section{Hasil Penelitian \\ Uji Validitas dn Realibilitas}

Hasil pengujian validitas dari 24 instrumen pernyataan, menunjukan instrumen dari variabel social media marketing $\left(\mathrm{X}_{1}\right)$, pay per click $\left(\mathrm{X}_{2}\right)$, email marketing $\left(\mathrm{X}_{3}\right)$, dan variabel keputusan Pembelian (Y) dinyatakan valid sebagai alat ukur pada variabel penelitian, dan masing-masing instrumen pada penelitian ini adalah reliabel dan layak untuk digunakan. Hasil uji validitas dan realibilitas dapat diartikan bahwa responden telah memahami dan responden konsisten pada butir-butir pernyataan.

Tabel 1. Pengaruh Secara Parsial Implementasi Digital Marketing Terhadap Keputusan Pembelian

\begin{tabular}{lcccccc}
\hline Variabel & Konstanta & $\begin{array}{c}\text { Koefisien } \\
\text { Regresi }\end{array}$ & $\begin{array}{c}\text { Standar } \\
\text { Error }\end{array}$ & $\mathbf{R}^{\mathbf{2}}$ & Nilai t & Nilai p \\
$\begin{array}{l}\text { Social media } \\
\text { marketing }\end{array}$ & 13.176 & 0,498 & 0,078 & 0,293 & 6.367 & $0,000^{*}$ \\
$\begin{array}{l}\text { Pay per click } \\
\text { Email }\end{array}$ & 7.568 & 0,710 & 0,068 & 0,527 & 10.449 & $0,000^{*}$ \\
marketing & 8.633 & 0,662 & 0,095 & 0,333 & 6.990 & $0,000^{*}$ \\
\hline
\end{tabular}

Berdasarkan Tabel 1, Social media marketing memberikan kontribusi sebesar $29,3 \%$, sedangkan sisanya $70,7 \%$ disumbangkan oleh variabel lainnya. Hipotesis $1\left(\mathrm{H}_{1}\right)$ yang menyatakan bahwa terdapat pengaruh implementasi Social Media Marketing terhadap keputusan pembelian dapat diterima. Hipotesis $1 \quad\left(\mathrm{H}_{1}\right)$, nilai koefisien regresi Social Media Marketing sebesar 0,498 yang dimaknai bahwa implementasi Social Media Marketing berdampak positif terhadap keputusan pembelian oleh 
konsumen sebesar 0,498 setiap kali adanya peningkatan aktivitas Social Media Marketing sebesar 1 satuan .

Pay per click memberikan kontribusi sebesar $52,7 \%$, sedangkan sisanya $47,3 \%$ disumbangkan oleh variabel lainnya. Pernyataan hipotesis $2\left(\mathrm{H}_{2}\right)$ bahwa terdapat pengaruh implementasi pay per click terhadap keputusan pembelian dapat diterima. Adapun hipotesis $2\left(\mathrm{H}_{2}\right)$, nilai koefisien regresi pay per click sebesar 0,710 yang dimaknai bahwa implementasi pay per click berdampak positif terhadap keputusan pembelian oleh konsumen sebesar 0,710 setiap kali adanya peningkatan aktivitas pay per click.

Email marketing memberikan kontribusi sebesar 33,3\%, sedangkan sisanya $66,7 \%$ disumbangkan oleh variabel lainnya. Hipotesis $3\left(\mathrm{H}_{3}\right)$ nilai koefisien regresi email marketing sebesar 0,662 yang berarti bahwa implementasi email marketing berdampak positif terhadap keputusan pembelian oleh konsumen sebesar 0,662 setiap kali adanya peningkatan aktivitas email marketing. Adapun pernyataan hipotesis $3\left(\mathrm{H}_{3}\right)$ bahwa terdapat pengaruh implementasi email marketing terhadap keputusan pembelian dapat diterima.

Tabel 2. Pengaruh Secara Simultan Implementasi Digital Marketing Terhadap Keputusan Pembelian

\begin{tabular}{lcccccc}
\hline Variabel & Konstanta & $\begin{array}{c}\text { Koefisien } \\
\text { Regresi } \\
-0,015\end{array}$ & $\begin{array}{c}\text { Standar } \\
\text { Error }\end{array}$ & $\mathbf{R}^{\mathbf{2}}$ & Nilai F & Nilai p \\
$\begin{array}{l}\text { Social media } \\
\text { marketing }\end{array}$ & & 0,600 & 2,028 & 0,533 & 38.699 & $0,000^{*}$ \\
$\begin{array}{l}\text { Pay per click } \\
\text { Email }\end{array}$ & 5.191 & 0,219 & & & & \\
marketing & & 0 & & & & \\
\hline
\end{tabular}

Dari Tabel 2, diketahui Nilai F hitung sebesar 38.699 lebih besar dibandingkan dengan $\mathrm{F}$ tabel 2,145, maka dapat diartikan terdapat pengaruh positif dan signifikan social media marketing, pay per click dan email marketing terhadap keputusan pembelian konsumen JD.id Jakarta.

Kontribusi social media marketing, pay per click, dan email marketing sebesar 0,533 atau 53,3\%, sedangkan sisanya $46,7 \%$ kemungkinan disumbangkan oleh faktor lainnya yaitu affiliate marketing, online advertsing dan search engine marketin yang tidak dibahas dalam penelitian ini. Artinya hipotesis $4\left(\mathrm{H}_{4}\right)$ yang menyatakan "terdapat pengaruh implementasi social media marketing, pay per click dan email marketing terhadap keputusan pembelian" dapat diterima.

Nilai koefisien regresi social media marketing sebesar -0,015 yang dimaknai terdapat hubungan yang tidak searah antara social media marketing. Hal ini berarti setiap peningkatan social media marketing sebesar 1 kali, maka keputusan pembelian akan menurun sebesar 0,015 kali. Selanjutnya nilai koefisien regresi pay per click sebesar 0,600 dengan nilai positif dan searah. Hal ini berarti setiap peningkatan pay per click sebesar 1 kali atau per 1 satuan, maka keputusan pembelian akan 
meningkat sebesar 0,600 kali. Nilai koefisien email marketing sebesar 0,219 dengan nilai positif dan signifikan. Hal ini berarti setiap peningkatan email marketing sebesar 1 kali, maka keputusan pembelian akan meningkat sebesar 0,219 kali.

\section{Pembahasan}

$\begin{array}{cl}\text { Hasil } & \text { penelitian yang } \\ \text { menunjukkan } & \text { terdapat pengaruh } \\ \text { implementasi yang positif dan }\end{array}$
signifikan social media marketing terhadap keputusan pembelian. Hal ini dapat dilihat dari apresiasi tertinggi yang diberikan oleh konsumen pada konten kreasi (creation content). Pengaruh implementasi social media marketing telah sesuai dengan apa yang diharapkan pada konsumen. Hasil penelitian ini sesuai dengan hasil penelitian Zanjabila dan Hidayat (2017) dalam konteks analisis pengaruh social media marketing terhadap keputusan pembelian di Bandung Techno Park, hasil penelitian ini menyatakan social media marketing memiliki pengaruh yang signifikan terhadap keputusan pembelian.

Hasil penelitian yang menunjukkan terdapat pengaruh implementasi yang positif dan signifikan pay per click terhadap keputusan pembelian. Hal ini dapat dilihat dari apresiasi tertinggi yang diberikan oleh konsumen pada pencarian (searching). Pengaruh implementasi pay per click terhadap kemudahaan dalam pencarian produk JD.id di google sudah sesuai diterapkan oleh perusahaan JD.id dan berdampak langsung kepada konsumen yang dalam hal ini konsumen merespon positif terhadap penerapan PPC. Hasil penelitian ini sesuai dengan hasil penelitian Erdem, et al (2017), menyatakan terdapat pengaruh signifikan word of mouth online, social media dan pay per click terhadap minat dan keputusan pembelian konsumen.

Hasil penelitian yang menunjukkan terdapat pengaruh implementasi yang positif dan signifikan email marketing terhadap keputusan pembelian. Hal ini dapat dilihat dari apresiasi tertinggi yang diberikan oleh konsumen pada promosi email (email promotion). Pengaruh implementasi email marketing terhadap promosi email dirasakan responden merupakan sarana promosi yang efektif dan tepat sasaran dalam hal ini penyampaian promosi dan komunikasi secara langsung melalui email sesuai dengan apa yang diinginkan konsumen. Hasil penelitian ini sesuai dengan hasil penelitian Simpson dan Mortimore (2015), menyatakan bahwa email marketing atau direct mail marketing masih merupakan metode periklanan yang sangat berpengaruh terhadap minat dan keputusan pembelian.

Hasil penelitian secara bersamasama terdapat pengaruh implementasi yang positif dan signifikansi dari pay per click dan email marketing terhadap keputusan pembelian. Secara bersamasama social media marketing mempunyai pengaruh berlawanan dikarenakan komunikasi pada pelayanan konsumen lewat sosial media dirasakan responden Walaupun cepat dan tanggap akan tetapi konsumen merasakan pemecahan masalah mengenai complain JD.id tidak memuaskan. Dibandingkan dengan pay per click dan email marketing yang notabene responden merespon positif terhadap perannya. 
Selain itu juga social media marketing mampu melakukan penyampaian konten promosi ke media sosial yang mudah dipahami konsumen dan hal ini mendapatkan apresiasi paling tinggi oleh konsumen. Dalam hal ini, Pay per click memberikan kemudahan kepada konsumen JD.id dalam memberikan informasi promosi melalui mesin pencarian google yang diberikan apresiasi tinggi oleh konsumen. Hal yang lain terdapat pada ke sungguh-sungguhannya perusahaan pada penerapan PPC yaitu dengan selalu mengupdate promosi setiap saat pada jejaring sosial dan dalam hal ini email marketing terhadap email promosi yang disampaikan secara efektif membantu konsumen dalam berbelanja di JD.id telah mendapatkan apresiasi tinggi dari konsumen. Selain itu tampilan email marketing yang kreatif dan inovatif mendapatkan respon positif dari konsumen. pada keputusan pembelian yang diberikan apresiasi tinggi ialah pada ke originalan dan bergaransinya produk yang dijual oleh JD.id. selain itu juga JD.id banyak menjual produk impor yang berkualitas tanpa harus repot memikirkan ekspedisi dan pajak yang ditanggung, karena itu sudah mencakup tanggung jawab dari JD.id. Dengan begitu secara bersama-sama terdapat pengaruh implementasi social media marketing, pay per click dan email marketing terhadap keputusan pembelian.

Hasil penelitian ini sesuai dengan hasil penelitian Reddy (2016), menyatakan bahwa konsumen telah memeluk digital marketing (social media marketing, pay per click, email marketing, Affiliate marketing, online advertising dan search engine marketing) dan mempengaruhi perilaku konsumen dan keputusan pembelian. Semakin besar pengaruh implementasi social media marketing, pay per click dan email marketing yang dilakukan perusahaan JD.id maka keputusan pembelian konsumen terhadap produk JD.id akan meningkat.

\section{KESIMPULAN DAN SARAN}

\section{Kesimpulan}

Hasil penelitian memberikan kesimpulan social media marketing terbentuk dari konten kreasi, komunitas, interaksi dan kepercayaan selain itu social media marketing melakukan penyampaian informasi mengenai promosi yang mudah dipahami melalui media sosial kepada konsumen hal ini mendapatkan apresiasi tertinggi. Kemudian pay per click terbentuk dari pencarian, tampilan dan jaringan sosial selain itu pay per click memudahkan konsumen dalam menemukan produk JD.id yang dibutuhkan di mesin pencarian google dalam hal ini mendapatkan apresiasi tertinggi. Dan email marketing terbentuk dari desain email, email promosi dan email inspirasi, selain itu email marketing membantu konsumen dalam berbelanja dan hal ini mendapatkan apresiasi tertinggi, sedangkan pada keputusan pembelian terdiri pilihan produk, merek, penyalur dan jumlah pembelian, dalam hal ini keputusan konsumen lebih memilih berbelanja produk pada JD.id dikarenakan semua produk JD.id original bergaransi hal ini mendapatkan apreasiasi tertinggi. Semua hal tersebut mendukung pernyataan bahwa terdapat pengaruh implementasi social media marketing, pay per click, email marketing 
terhadap keputusan pembelian, baik secara parsial maupun secara simultan.

\section{Saran}

Hasil penelitian menunjukkan perlu adanya rekomendasi berupa saran, baik untuk penelitian selanjutnya, perusahaan, dan bisnis. Untuk penelitian selanjutnya disarankan dapat menambahkan variabel lainnya yaitu affiliate marketing, online advertsing dan search engine marketing dalam konteks digital marketing yang tidak dibahas pada penelitian ini. Untuk perusahaan (JD.id), perlu memperhatikan dan mengembangkan pengetahuan customer service JD.id mengenai apa yang dibutuhkan dan diinginkan konsumen melalui media sosial sebagai interaksi langsung kepada konsumen. Untuk praktisi bisnis penting untuk di elaborasi lagi dan diterapkan hasil penelitian ini khususnya penerapan digital markerting untuk mendukung optimalisasi pemasaran perusahaan.

\section{DAFTAR PUSTAKA}

Arikunto, S, (2013), Prosedur Penelitian: Suatu Pendekatan Praktik, Jakarta: Rineka Cipta

As'ad H, Abu Rummandan Anas Y, Alhadid, (2014), The Impact of Social Media Marketing on Brand Equity: An Empirical Study on Mobile Service Provider in Jordan, Science Private University, Amman, Jordan. Rev. Integr, Bus, Econ, Res Vol 3

Asean, Up, (2018), Top 10 Ecommerce Sites in Indonesia 2019, (ONLINE), Available, https://aseanup.com
Chaffey, D, (2011), E-commerce \& Ebusiness Management 5th Edition, New Jersey: Prentice Hall

Chi, Hsu-Hsien, (2011), Interactive Digital Advertising VS. Virtual Brand Community: Exploratory Study of User Motivation and Social Media Marketing Responses in Taiwan, Journal of Interactive Advertising, 12: 4461

Damodar N., Gujarati dan Dawn C, Porter, (2012), Dasar-dasar Ekonometrika, Buku 2, Edisi 5, Raden Carlos Mangunsong (penj.), Jakarta: Salemba Empat

Dharmmesta, Basu Swastha., Handoko, T, Hani, (2012). Manajemen Pemasaran Analisis Perilaku Konsumen, Edisi Pertama, BPFE, Yogyakarta

Duwi, Priyatno, (2010), Teknik Mudah dan Cepat Melakukan Analisis Data Penelitian dengan SPSS dan Tanya Jawab Ujian Pendadaran, Gaya Media, Yogyakarta

Erdem, Durmus, Ozdemir, (2017), The Relationship With Ad Click and Purchase Intention: An Empiricial Study of Online Consumer Behaviour, European Journal of Economics and Business Studies, Vol, 9, Nr, 1

Fariborzi, E dan Zahedifard, M, (2012), E-mail Marketing: Advantages, Disadvantages and ImprovingTechniques,

International Journal of $e$ Education, $e$-Business, $e$ Management and e-Learning, Vol, 2

Florez, Escobar, Restrepo, Botero, Arias, (2018), Influence of Social Network on the Purchase 
Decisions of University Students, Management Notebook Journal, Vol,18, Hal, 61-84

Ghozali, Imam, (2016), Aplikasi Analisis Multivariete Dengan Program IBM SPSS 23, Edisi 8, Cetakan ke Delapan, Semarang : Badan Penerbit Universitas Diponegoro

Gunelius, Susan, (2011), 30-Minute Social Media Marketing, United States: McGraw-Hill Companies Kotler, Philip and Gary Amstrong, (2016), Prinsip-prinsip Pemasaran, Terjemahan Edisi13, Jilid 1, Jakarta: Erlangga

Kotler, Philip and Kevin Lane Keller, (2016), Marketing Management, (16thEdition), New Jersey: Prentice Hall Published

Kriyantono, Rachmat, (2010), Teknik praktis riset komunikasi: disertai contoh praktis riset media, public relation, advertising, komunikasi organisaso, komunikasi pemasaran, Jakarta: Kencana

Mahalaxmi, Ranjith, (2016), A Study on Impact of Digital Marketing in Customer Purchase Decision in Trichy, International Journal for Innovative Research in Science \& Technology (IJIRST), Vol, 2, Issue, 10

Malik, Rao, (2017), Impact of Digital Marketing on Youth Buying Behaviour at Big Bazaar in Udupi, International Journal for Innovative Research in Science \& Technology (IJIRST), Vol, 3, Issue, 08

Nizar, janathanan, (2018), Impact of Digital Marketing on Consumer Purchase Behaviour, APIIT
Business, Law \& Technology Conference

Purwana. ES, Rahmi, Aditya, (2017), Pemanfaatan Digital Marketing Bagi Usaha Mikro Kecil dan Menengah (UMKM) di Kelurahan Malaka Sari, Duren Sawit, Jurnal Pemberdayaan Masyarakat Madani (JPMM), Vol, 1, No, 1

Reddy, Girshwyn, (2016), Digital Marketing Impact on the Consumer Decision Making Process in Nike's Customer Retaik Operations in South Africa, Skripsi, University of Pretoria

Ryan, D dan Calvin Jones, (2009), Digital Marketing : Marketing Strategies for Engaging Digital Generation, Kogan Page Limited, London

Sanjaya, Ridwan dan Josua Tarigan, (2009), Creative Digital Marketing, PT Elex Media Komputindo, Jakarta

Simpson, James and Mortimore, Helen, (2015), The Infulence of Direct Mail Marketing on Buyer Purchasing Decision: A Qualitative Analysis of Perceptions by Age Group, Journal of Research Studies in Business and Management, JRSBM: 1/1 pp119-142.

Siregar, Syofian, (2013), Metode Penelitian Kuantitatif, Jakarta: PT Fajar Interpratama Mandiri

Sivasankaran, (2017), Digital Marketing and Its Impact on Buying Behaviour of Youth, International Journal of Research in Management \& Business Studies (IJRMBS), Vol, 4, 
Stephen. (2015), The Role of Digital and Social Media Marketing in Consumer Behavior, Tesis, University of Oxford

Stokes, R, (2011), eMarketing: The Essential Guide to Digital Marketing, Edisi Empat, Quirk Pty Ltd

Sugiyono, (2017), Metode Penelitian Pendidikan Pendekatan Kuantitatif, Kualitatif, dan $R \& D$, Bandung, Alfabeta.
Toor, Husnain and Hussain, (2017), The Impact of Social Network Marketing on Consumer Purchase Intention in Pakistan: Consumer Engagement as a Mediator, Asian Journal of Business and Accounting, Vol, 10, No, 1

Zanjabila, Hidayat, (2017), Analisis Pengaruh Sosial Media Marketing Terhadap Keputusan Pembelian Bandung Techno Park Studi Pelanggan Bandung Techno Park, E-proceeding of Applied Science, Vol, 3, No, 2, Hal, 368. 
